RHYTHM AND RACE IN MODERNIST POETRY AND SCIENCE 


\section{Michael Golston}

Columbia University Press New York 
RHYTHM AND RACE IN MODERNIST POETRY AND SCIENCE 
COLUMBIA UNIVERSITY PRESS

Publishers Since 1893

NEW YORK CHICHESTER, WEST SUSSEX

COPYRIGHT (C) 2008 COLUMBIA UNIVERSTT PRESS

ALL RIGHTS RESERVED

LIBRARY OF CONGRESS CATALOGING-IN-PUBLICATION DATA

Golston, Michael.

Rhythm and race in modernist poetry and science / Michael Golston.

p. $\mathrm{cm}$.

Includes bibliographical references and index.

ISBN 978-0-23I-I4276-2 (cloth : alk. paper) — ISBN 978-0-23I-5I233-6 (ebook) I. American poetry-2oth century-History and criticism. 2. Modernism (Literature). 3. Pound, Ezra, I885-I972-Knowledge-Science. 4. Williams, William Carlos, I883-I963Knowledge-Science. 5. Yeats, W. B. (William Butler), I865-1939-Knowledge-Science. 6. Rhythm-

Political aspects. 7. Racism in literature. 8. Literature and science-History-2oth century. 9. Politics and literature-History-2oth century. I. Title. PS3I0.M57G66 2007 $8 \mathrm{II}^{\prime} \cdot 5209 \mathrm{II} 2-\mathrm{dc22}$ 2007021125 
For my mother, Helga Golston, and for Cherrymae, Azara, and Chris 

All the mortalities merge in the definition of "rhythm" -Lyn Hejinian, The Cell 
